\title{
Strata of the Political: Epigenetic and Microbial Imaginaries in Post-Apartheid Cape Town
}

\author{
Michelle Pentecost \\ Institute for Social and Cultural Anthropology, University of Oxford, Oxford, UK and The First \\ Thousand Days Research Group, University of Cape Town, Cape Town, South Africa; \\ michelle.pentecost@gtc.ox.ac.uk

\section{Thomas Cousins} \\ Department of Sociology and Social Anthropology, Stellenbosch University, Stellenbosch, \\ South Africa; \\ tcousins@sun.ac.za
}

\begin{abstract}
The epigenetic and microbiomic imaginaries that animate public health discourse on perinatal nutrition and the infant gut in South Africa offer a case study through which to reconsider the ontological presuppositions of "space" that frame epigenetic biopolitics. We suggest that the mutual constitution of the relations at stake in and around questions of nutrition, mothers and infants, the gut and sanitation in Khayelitsha, can be understood through a Deleuzian geomorphological image of "strata of the political". Strata are conjunctural entanglements that temporarily stabilise when distinctions hold briefly, and that bring into alignment particular relations and forces that distribute life and non-life. This analytic makes visible and available to political life the spatio-temporal, socio-natural blurring of categories that epigenetic and microbiomic discourses could afford. Grounded ethnographic descriptions of these processes of "mattering" can challenge political epistemologies and take further critical perspectives on space to open up possibilities for a robust postgenomic politics.
\end{abstract}

Keywords: epigenetics, microbiome, governance, nutrition, sanitation, space

\section{Introduction}

It was March 2015 and the dry summer heat had not yet abated in Khayelitsha. As Cape Town's largest township, it was established in 1983 on the sandy dunes and wetlands between the Table Mountain and Hottentots Holland mountain ranges, along the rocky shores of False Bay. On this day the wind whipped up the sand so that it sedimented everywhere-in collars and braids, between toes, and under fingernails. Nonyameko sent a friend to fetch us from the road where we had parked, on the edge of the shack-lands that extend from Khayelitsha's coastal border towards its other boundary: the N2 highway that connects cosmopolitan Cape Town with the winelands district some 15 minutes away. We were led down a winding sandy path covered by old carpeting to a makeshift yard with a makeshift wooden gate into an ante-room with an old fridge, a small table with stacked plastic tupperwares and a vegetable tray with a few onions. We found Nonyameko hushing her three-day-old infant as the wind rattled the shack's zinc facade. 
Nonyameko came to Khayelitsha in late 2014 when she was four months pregnant as she felt it would be better to deliver her baby in Cape Town than in Vredendal, a rural town in the north of the Western Cape province, where she worked on a farm picking, packing and storing cucumbers. She was born in 1991 in the rural village of Lusikisiki in the Eastern Cape, and lived there until she left the family home to find work. She had heard via word of mouth about work on this farm, and so she had made the long journey (a taxi to Mthata, and then another taxi to Beaufort West, and then a hitchhike with a truck driver after a three-hour wait). While we sat with Nonyameko, two women arrived at the door. They were wearing light blue golf shirts bearing a small logo of mother and child, and they introduced themselves as "mentor mothers" from a local organisation. They explained that they had come to weigh the baby and clean the umbilical cord. The mentor mother put down her backpack and unpacked surgical spirits, cotton swabs and her scale. She was efficient and business-like in her instructions and explanations as she went about her tasks. She set down the scale on the floor and explained that she needed to calibrate it. She demonstrated how to zero the scale and checked that it was working by weighing herself first. A straight line of zero's flashed up on the screen: "Is it working?", I asked her. "Yes, it is working, but the floor is not level", she said.

She picked up the scale, and moved it to the other end of the room to start the process again. This time she managed to calibrate the scale, and she read her weight: 90 kilograms. She nodded, and asked Nonyameko to hand her the baby. To weigh the infant she held her while standing on the scale again and then subtracted her weight from the total: "4.2 kilograms". She recorded this in a Croxley A4 notebook. The mentor mother advised Nonyameko to keep on with the breastfeeding, and advised her not to mix feed as it would increase the risk of diarrhoea.

The encounter with Nonyameko and the mentor-mother, in which the electronic scale must contend with the sandy dune floor of this home in Khayelitsha, provides the first ethnographic frame for this paper. The second frame concerns the microbial politics and activism that has grown in Khayelitsha since 2011. A few months prior to the meeting with Nonyameko, we attended a Social Justice Coalition (SJC) press conference not far from Nonyameko's home, which announced the findings of a "social audit" the SIC had conducted on the janitorial service for communal flush toilets in Khayelitsha. Surrounded by a long row of broken public toilets, raw sewage flowed alongside the press conference table into the wetland between the N2 highway and the informal settlement. Axolile Notyala, project manager for the SJC, opened the proceedings with a diagnosis:

A service, which costs almost R60 million of public money, and which could have a major impact on the lives of informal settlement residents, is failing. Residents are left without access to safe and dignified toilets, posing life-threatening risks to workers and to the poorest and most vulnerable communities in the city (Thamm 2014:1).

As the activists spoke with eloquence, clarity, and force, a herd of cattle crested the rise behind the toilets, with minder and dog watching as they waded into the river.

These fieldnotes come from fieldwork in Khayelitsha, where the authors have worked and conducted research since 2003 (Cousins 2007, 2008). Pentecost's 
fieldwork in 2014-2015 examined how national nutrition policy in South Africa has changed in response to emergent knowledge in the fields of Developmental Origins of Health and Disease (DOHaD) and epigenetics; the implications this has in the clinical setting; and how this might correspond with local realities of perinatal nutrition in this place. Nonyameko is one of a group of 15 women Pentecost followed closely over the course of a year. Cousins' ongoing fieldwork in this settlement is concerned with the microbial life of gastro-enteritis, and the political ecology of diarrhoea in post-apartheid Cape Town. Together, we seek to interrogate how new imaginaries of epigenetics and microbiome science-discourses arising largely out of scientific work done in the global North-come to bear on public health logics in the global South. The first imaginary is the new logic that frames obesity and malnutrition as outcomes of programming events during the first thousand days of life, based on $\mathrm{DOHaD}$ research that draws on the language of epigenetics (Black et al. 2013). The second is the microbial imaginary that now animates research on the gut microbiome and immunity (Kau et al. 2011).

Our aim is to take current work on epigenetic biopolitics a step further by reconsidering the ontological presuppositions concerning "space" that frame this field, through a description of the interdigitation of microbial, geological and political processes that constitute the nutrition-sanitation nexus in Cape Town. Following Elizabeth Povinelli's (2015) notion of "geontology", and extending Hinchliffe and Ward's (2014) "geographies of folded life", we suggest that the mutual constitution of the relations at stake in and around questions of food and nutrition, mothers and infants, the gut and sanitation in Khayelitsha, can be understood in terms of the twists and torsions suggested by a geomorphological image of strata. We work with strata less as an additive strategy for holism redux than as a possibility for noticing the conjunctural processes that bring into alignment particular relations and forces that distribute life and non-life, as critical perspectives on space and biology suggest (Massey 2005; Meloni 2016; Warin et al. 2016). Utilising speculative materialist approaches, our ethnographic work tracks the deployment of new kinds of actors across different scales of time and space, and asks if it might be possible to pose more pointed ethical and political questions of the regimes of governance premised on those forms of life at stake in places often framed as zones of abandonment.

\section{Postgenomic Worlds}

That research and public health policy in South Africa and elsewhere now hinges on postgenomic concepts such as "epigenetics" and "microbiomics" is emblematic of the rapid uptake of these ideas in research and policy discourse in recent years. Philosophers of biology and social scientists have closely interrogated this phenomenon-and contributed to the hype. Pickersgill et al.'s (2013) seminal paper on the social dimensions of epigenetics rightly highlights how this science has been constructed as new in scientific discourse and in its social analysis; in both cases epistemic modesty and epistemic ostentatiousness abound (Pickersgill 2016). First conceived by Conrad Waddington in the 1940s, the term epigenetics is not new, but has changed in meaning in step with its formalisation as a subfield of biology 
(Jablonka and Lamb 2002). Waddington (1942) derived it from the Aristotelian concept of epigenesis, which describes the qualitative and continuous nature of development, and illustrated the concept with his "epigenetic landscape". This geomorphologically inflected image depicts a network of valleys and hills on an inclined plane that must be negotiated by a marble that rolls through the landscape via a series of binary options. The marble represents the developmental outcome; the final path taken is a function of gene-network interactions modulated by environmental factors (Slack 2002:891).

That epigenetics remained unpopular until the 21 st century is less a reflection of the underlying science, and more an example of what Maurizio Meloni (2016) has termed "political biology": that knowledge claims must overcome "the constraints imposed by acceptable-that is to say, recognised-epistemic statements and available sociopolitical values" (Meloni 2016:18). Today molecular biologists use the term "epigenetics" to refer to the process by which genetic material and its surrounding matrix of compounds (the epigenome) modulate environmental inputs to affect gene expression without changes to the DNA sequence. The best described epigenetic phenomenon is DNA methylation whereby marks on the epigenome manifest during development in response to environmental cues, of which nutritional signals are thought to be especially important. These "methylation signatures" are measurable by genome analysis and persist into maturity, as a number of cohort studies have shown (Godfrey et al. 2011; Heijmans et al. 2008; Tobi et al. 2009). The picture is complicated further by new understandings of how microbial populations form the bulk of our being and have a prominent role in the workings of the gut, brain and immune system (Wilson 2004). As John Dupré (2015) has argued, the Human Microbiome Project is widely considered as the indispensable compliment to the Human Genome Project as metagenomic analysis develops our understanding of the genetic resources of the gut microbiome.

This convergence of epigenetic and microbiome science finds its meeting point in the infant metabolome, with a burgeoning literature on the links between stunting, malnutrition and sanitation (Spears et al. 2013); the developmental origins of obesity and the infant microbiome (Edwards and Parrett 2002; Thompson 2012); and the role of epigenetics and the microbiome in the development of immunity and non-communicable disease (Prescott 2013). In policy terms, this has translated into a focus on maternal and child health in two areas: first, nutrition interventions during "the first thousand days of life", premised on DOHaD and epigenetic concepts (Black et al. 2013), and second, measures to improve sanitation and thus decrease waterborne disease and malnutrition, premised on the microbiome as the centre of the nutrition-sanitation nexus (Silver and Singer 2014).

The notion of the genome as "the blueprint for human life and disease", as Richardson and Stevens note, is disrupted by "fields such as microbiomics and metagenomics ... [that] confute the notion of the human genome as a contained and complete record of the genomic content of the human body" (2015:235). However, as a number of scholars have cautioned, the significance of microbiome science and "the epigenetics revolution" is uncertain and should be closely scrutinised (Hanage 2014; Meloni and Testa 2014; Waggoner and Uller 2015). In the case of epigenetics, scholarship has focused on a troubling paradox: that this science could 
potentially reintroduce socio-political processes into more "plastic" conceptions of body and environment, to show how the transgenerational imprinting of experience shapes local biologies (Lock 2013; Meloni 2015); conversely that there is also the risk of a reconstituted biological determinism (Guthman and Mansfield 2013; Lock 2013). The potential to reinvigorate understandings of "environment" may in practice reinforce liberalised notions of the individual and individual responsibility for health outcomes (Landecker and Panofsky 2013; Mansfield 2012), with the maternal body as a central target of this discourse (Lamoreaux 2016; Landecker 2011; Mansfield 2012; Richardson 2015; Warin et al. 2012; Yates-Doerr 2011).

Strategies for how social scientists might comprehend "the body in the era of the epigenome" (Lock 2015), have included the "embedded body" (Niewohner 2011); reinvigorated "local biologies" (Lock 2013); and "biosocial becomings" (Ingold and Palsson 2013). Geography's attention to the body/environment question is best summarised by Guthman and Mansfield (2013), who suggest that environmental epigenetics emphasises complex temporalities that challenge methodologies that privilege space. They outline three ways in which geography has understood the body/environment relationship, namely environmental determinants of health; political ecology of health; and social studies of biomedicine. The first takes space/ place as causal, thereby black-boxing the environment. Political ecology works with a more expanded notion of environment, to include active processes that are simultaneously political and biophysical, and hence "socionatural" (Guthman and Mansfield 2013:490). Finally, studies of biomedicine have paid attention to new biomedical and life science understandings of life, health, and bodies at the frontiers of biomedicine, focused on the "molecularisation" of life, but have tended to miss the environmentalisation of the chemical molecule (Guthman and Mansfield 2013:491). Guthman and Mansfield usefully draw these three insights together to make the case for an environmental epigenetics in which both nature and nurture are abandoned for an understanding of the body as always changeable, influenced by "biosociochemical" pathways acting at multiple sites, from the cell nucleus (e.g. DNA methylation) to the global atmosphere (e.g. transport of chemicals). They suggest that environmental epigenetics reveals how health disparities are not only spatial but also historical/temporal, and argue for a de-privileging of space in certain traditions of geography (Guthman and Mansfield 2013:499).

Those familiar with a more critical reading of space, as Doreen Massey's (2005) work suggests, would be sympathetic to the de-essentialising possibilities here: if space is the product of "relations-between", is embedded in material practices, characterised by multiplicity, coexisting heterogeneity, and always under construction, then it becomes possible to sense the passing and contingent conjunctural qualities of "space"-what Massey calls a "simultaneity of stories-so-far" (2005:9). Our aim is to take forward Massey's sense of place not as point or area on a map, but as integrations of space and time; as spatio-temporal events (Massey 2005:130), or what we term strata. Thinking with Karen Barad's (2003) concept of "intra-action", which avoids presuming pre-existing actors, but rather emphasises the emergent and dependent relations that actions engender, strata can be understood as emergent, immanent, spatio-temporal relations whose variability and difference become sensible through friction (cf. Tsing 2005). 
In this interrogation of what we call "epigenetic and microbial imaginaries" in Cape Town, we are aware that, as Pickersgill and colleagues note, "the translation of analytic strategies and explanatory frameworks between different cases studies is not an 'innocent' activity; it enacts the world in particular ways" (2013:442). Our aim is not to reinforce the hype concerning epigenetics and microbiome science, and we do not take these concepts at face value. Rather, we approach them as objects in the policy, research, and clinical landscapes of public health in Cape Town with a view to opening up an alternative reading of the political and ethical terrain at stake. We offer a situated material context in which to consider recent debates about how best to understand "the intricacies of biopolitics" (Meloni 2010:564), and by extension, epigenetic biopolitics: "the wide-ranging change in how life-nature, bodies, biology, and environments-is understood, but also taken hold of and governed" (Mansfield 2012:354). If, as Maurizio Meloni cautions, "forms of bios have been made and remade over history" then close attention to "concrete historical practices and situated material contexts" (2016:24) is required if we are to make sense of the present configurations of bios and the forms of governance they permit (cf. Povinelli 2015).

\section{Epigenetics and the Everyday in an Informal Settlement}

Epigenetic discourses, largely produced by research done in the North, nevertheless increasingly come to bear on public health strategies in the South. Pentecost's present work interrogates how new scientific discourses couched in the language of epigenetics and DOHaD now configure South African nutrition policy to focus on "the first thousand days of life". The research fields of DOHaD and epigenetics place obesity in a pattern of intergenerational cycles where altered maternal nutrition, including both under- and over-nutrition, leads to the transgenerational transmission of metabolic disorders via epigenetic mechanisms (Hochberg et al. 2010). Contemporary epidemiological life course theory employs theories of nutrition transition and developmental programming to understand the aetiology of non-communicable disease in developing settings (Popkin et al. 2011). The surveillance of Nonyameko and her newborn is one expression of this logic, which focuses on early life-from conception until the age of two years-as a target period to prevent child undernutrition in the present, to create future human capital, and to prevent a potential burden of obesity and chronic disease in the future (Black et al. 2013). In the antenatal clinics of Khayelitsha where Pentecost conducted fieldwork, each pregnant woman received a pocket-sized peachcoloured booklet, titled Feeding Smart From the Start, which explained that: "The first 1,000 days of a child's life (from when a woman falls pregnant to when her child turns two) is a very important time for shaping a child's ability to grow and develop". This message was reinforced during antenatal visits. One health promoter explained the consequences of infant feeding practices as follows:

Whatever you give the child, it goes in the gut and it makes cracks, and those cracks are the entry point for any virus. These things can happen to a child whether they are HIV 
positive or HIV negative. So you can't give the child food at all, at all. At the age of 0-5 months, they don't have those acids that break down food. If you mix feed, you are introducing the baby to diabetes, to hypertension. You can see your child: maybe he gets diabetes or hypertension, because you as a parent, you introduced her to food at an early age. Those chemicals-they increase the pressure of a child to get fat, and then you will always have to go to the clinic.

The clinic is thus a mediating site between the new nutrition policy that incorporates epigenetic notions of transgenerational disease transmission, and the people who are the focus of this discourse.

The notion that new scientific knowledge takes hold only insofar as it is politically acceptable (Meloni 2016) offers some explanation for why DOHaD and epigenetics has been harnessed less for explaining current burdens of disease inequality in South Africa, and more for a future-oriented outlook that aligns with national aspirations. Pentecost (2013) has written earlier about the need to contextualise new knowledge within the fields of development programming and epigenetics as applied to understandings of obesity and chronic disease in South Africa within a historical and socio-political framework. In contrast, however, the notion of epigenetic transgenerational disease is mobilised in South African public health discourse, as elsewhere (Warin et al. 2012; Yates-Doerr 2011), to extend responsibility for future health outcomes to new mothers, who are cast as "empowered" citizens carrying the future health of their children, and of the nation (cf. Fassin 2013).

\section{Governing Microbes, Governing the Gut}

What of Nonyameko's infant, and the mentor mother's warning of her increased risk of diarrhoea if she is mixed fed, and the health promoter's warnings about the infant gut? The logic of microbial governance enters into public health discourse anew in the stitching together of epigenetic and microbiome imaginaries. There is an emerging public health concern with how the gut microbiome plays a key role in infant immune system development and growth. Research from Zambia (Kelly et al. 1997), the Gambia (Campbell et al. 2003), Zimbabwe (Prendergast et al. 2014), Bangladesh (Lin et al. 2013), and Brazil (Fagundes et al. 1994) supports the notion that the movement of bacteria across a compromised gut mucosa leads to inflammation and subsequent growth impairment. Mbuya and Humphrey (2016:116) suggest that environmental enteric dysfunction is caused by "[c]hronic exposure to a contaminated environment [which] creates a constant state of survival responses characterized by loss, malabsorption, maldigestion, and inefficient utilization of nutrients". Their claim is that in the context of marginal diets and recurrent infections, this "impoverished gut" condition likely explains a significant portion of the unresolved stunting affecting one in every three children in developing countries (Mbuya and Humphrey 2016:107).

In the South African context, such knowledge claims encounter a distinct political history of HIV and nutrition. As Cousins (2015) has shown, the history of HIV from AIDS denialism to the subsequent provisioning of ART has indelibly shaped the meaning of nutrition in South Africa, but it has also produced new scientific understanding of the role of the gastrointestinal tract in HIV and immune system 
functioning. Apart from the shifting political grounds for claims about nutrition, these insights have spurred a plethora of new gastroenterological projects in South Africa. For example, research from the University of Cape Town's Institute of Infectious Disease and Molecular Medicine suggests that the gut microbiome plays a key role in infant immune system development (Jaspan 2015). HIV-exposed babies are thought to have gut dysbiosis and thus different vaccine responses. This work seeks to confirm whether infants born to mothers with dysbiosis have altered early gut microbiomes, which suggests that manipulation of the gut microbiome could assist with improving infant immunity. The infant gut is already a site of intervention in South African perinatal policy, which focuses on exclusive breastfeeding for six months to mitigate the risk of HIV transmission associated with mixed feeding and the increased risk of diarrhoea that accompanies formula feeding (Doherty and Sanders 2011; Saloojee et al. 2011; Zunza et al. 2011). Further, childhood diarrhoea claims several hundred lives in Cape Town every year, with the "diarrhoea season" peaking between November and May. The Diarrhoea Task Force established in 2004 has managed to reduce the number of under-fives dying from acute gastroenteritis (Westwood and Claasen 2010), although they are still confounded by the problem of how to understand the general incidence of diarrhoea "in the community" (i.e. the poor in townships on the city's margins). ${ }^{1}$ In more explicit biopolitical terms, one could say that the children that fill out the rehydration wards every summer have become figurations of letting live and making die in the new metabolic regimes of post-Apartheid Cape Town and of the governance of microbial life. Their figuration is spatially expressed as a function of what is referred to in South Africa as "informal settlements", or "townships", or "locations". The striations of race and class thus produce a differential distribution of diarrhoea across the city, which requires tracing the intra-actions and involutions of histories of racial governance, hunger, and microbial life.

\section{Epigenetic and Microbial Conjunctures}

The epigenetic and microbiomal imaginaries that animate the "first thousand days" campaign and new research interests in immunity and the microbiome thus intersect in the infant metabolome, to produce the logic that it is the manipulation of the individual perinatal diet and gut microbiome that should be the end target of interventions, rather than a more radical engagement with the political ecology of nutrition, HIV and enteric infection. In considering epigenetic and microbial imaginaries together in the specific ethnographic context of post-apartheid Khayelitsha, we seek to explore how critical perspectives on space might offer a route for opening up questions of power in the intersections of emerging knowledge claims and policy orientations.

Shostak and Moinester (2015) point out that postgenomic science is split by a fundamental tension between approaches to the environment that frame it as a molecular, individual trait and those that focus on multiple levels of analysis and techniques of measurement. The first, characterised by "exposomics", takes environmental exposures to encompass a wide variety of external and internal factors relevant to human biological processes and their health effects, beyond a 
"parochial" environmental epidemiology that divides exposures into categories such as air and water pollution, occupation, diet and physical activity, and stress. While exposomics tends to focus on "the body's internal chemical environment" (Shostak and Moinester 2015:197), ecological approaches focus on the larger environmental context in an attempt to make visible social institutions and processes that bear on individual and population health outcomes in ways not explicable in studies that focus solely on individuals or their internal chemical environment (Shostak and Moinester 2015:201). In outlining these orientations to "environment" in postgenomic sciences, Shostak and Moinester show that there is no consensus about what is meant by "the environment" or how it should be measured. Rather, the specific techniques of measuring the environment create "regimes of perceptibility" in which particular aspects of the environment become more or less visible. At stake for us here is the way in which such regimes of perceptibility "regularize, standardize, and sediment the contours of perception and imperception" (Shostak and Moinester 2015:195).

For Elizabeth Povinelli, these regimes of perceptibility are governed by what she terms geontopower, a formation of power in which "the problem of the present is not the governance of and through life, but the maintenance of the distinction between life and non-life" (2015:170). Likewise thinking with Roberto Esposito, Hinchliffe and Ward argue that immunity-distinct from the logic of biopolitical regulation and biosecurity where "life is preserved inside an order that excludes its free development because it is retained within the negative threshold defined by its opposite" (Esposito 2011:10)_provides a framework in which life-organic and inorganic, virus and human, microbe and milieu-is a "continuously changing world, a borderlands of folded relations, within which health is made and re-made" (Hinchliffe and Ward 2014:143). Extending Hinchliffe and Ward's "geographies of folded life" and Warin et al.'s (2016) use of a Deleuzian metaphor of the fold to conceptualise epigenetics, we suggest thinking organic and inorganic, life and non-life, agent and milieu, event and process in relation to both folds and strata. We use strata as a material analytic that may offer an opening of body/environment and space/time conjunctures to different political readings. As such, what we might call a geomorphological sensibility (cf. Deleuze and Guattari's [1987] "geology of morals"), provides a way to think through the complex relations of time and experience in the making of the local biologies we have documented in our fieldsite.

\section{Strata of the Political}

To illustrate, we should return to Nonyameko, in her dusty shack with its unlevel floor, composed of carpeting over a sandy dune, between zinc sheets that rattle in the wind. What happens when the geomorphology that shapes this dune comes into a more visible relation with the weather and climate patterns of Khayelitsha, given its coastal proximity; the built environment of a settlement that remains largely informal; the bacteria, viruses and microbes that circulate through this space; neighbours, kin, building materials, gas cookers, prepaid water and electricity meters, porta-loos, and highways? Taking further the notion of a situated urban political ecology through African urbanism (Lawhon et al. 2014), we suggest 
tracing five possible strata for our case, which should be understood less as discrete objects or layers of knowledge than as interdigitated or invaginated folds that constitute contemporary life worlds in Khayelitsha and elsewhere.

The first stratum consists in the particular geology and geomorphology of the Western Cape that has produced the sandy dunes on which Khayelitsha is built, and on which our health care worker tried to balance her scale to weigh Nonyameko's baby. The oldest geological formations in the Western Cape belong to the Malmesbury Group of rocks that make up the basement of the area. Around 540 million years ago, the Cape Granite Suite formed as a series of intrusions. The geological template of the Table Mountain Group rocks that overlie the Cape Granite Suite are quartzitic sandstones deposited on the sea-floor around 500 million years ago. The $2 \mathrm{~km}$ thick Table Mountain Sandstone formation, from which many of the mountains around Cape Town are formed, was eroded over the last 400 million years so that the middle portions were removed, creating the Cape Flats. The unconsolidated sands of the Sandveld Group are the youngest of the geological strata in the Peninsula, and overlie the bedrock of the Malmesbury Group and Cape Granite of much of the Cape Flats. These are deposits of river-, sea-, wind- and estuarine-derived sediments, the most recent being the Witzand Formation, which is only 6000 years old, and is composed of the vegetated and unvegetated calcareous dunes that characterise Khayelitsha, Mitchell's Plain and the False Bay coastline (Holmes and Meadows 2012). Today, this area is seen less as a geomorphological phenomenon than as "apartheid's dumping ground" (Legassick 2006). The sands that condition the calibration of the scale in Nonyameko's case bring into conjuncture these geomorphological processes with the racialised political history that frames her encounter with the mentor mother in Khayelitsha.

A second stratum is this political history of urban segregation as a product of what Maynard Swanson (1977) named the "sanitation syndrome". South Africa's first urban segregation was inspired by Cape Town's response to the bubonic plague in 1901, when "Africans" were seen to be responsible for the spread of disease. Their removal from the city established the pattern for forced removals and urban segregation over the next century. Race-based legislation from the 1950s, including the Group Areas Act, forced people classified as black or coloured out of established urban areas, which were designated for people classified as white. ${ }^{2}$ The materialisation of a century of the "sanitation syndrome" in Cape Town now means that to be black is to be poor is to be spatially marginalised, is to be infrastructurally compromised, is to be immersed in an abundance of microbial and viral life. Nonyameko's trajectory from Lusikisiki, in the former homeland of the Transkei, ${ }^{3}$ to Vredendal, a previously whites-only agricultural town, where she struggled to navigate the Afrikaans language health care system, to the urban fringe of Cape Town, maps onto a broader social history of racialised labour migration between African homelands and urban centres and an accelerated postapartheid urbanisation of black South Africans (Lohnert et al. 1998). Like many other migrants to the city, Nonyameko found herself on the informal outskirts of Khayelitsha precisely because well-trodden routes and social networks make possible a foothold in the city. Khayelitsha means "new home", and began as a planned settlement in the early 1980 s as a solution to the problems of overcrowding and political unrest in the 
existing townships nearer the city centre. The land designated for Khayelitsha was chosen specifically for its lack of desirability for agriculture or habitation, given its sandy soil and rocky coastline. Today, the township remains Cape Town's terrae incognitae: unmapped both in terms of its incomplete cartography, and its exclusion from the social landscape of the city (Brunn and Wilson 2013).

The third stratum consists in the combination of topography, climate, and ocean currents that produce what is known as the Southern Cape Condensation Problem Area (SCCPA). Extending from East London to Malmesbury, the boundary is formed by a combination of location relative to the Southern Cape mountain ranges and areas of high rainfall, and seasonal variation. Khayelitsha forms part of the western belt of the SCCPA. Half of Khayelitsha residents live in informal dwellings, and like Nonyameko, in overcrowded conditions. The mould growth associated with increased condensation in the belt is thought to undermine the structural integrity of low-cost housing and to contribute to the dismally high levels of respiratory diseases (including tuberculosis) found in the Western Cape (Matthews et al. 2003; cf. Canadian Tuberculosis Committee 2007). Air quality in Khayelitsha is further compromised by the frequent burning of wood, tyres and household waste, and from dust blown into the wind; the average levels of inhalable particulate matter in the township are 70 times that of measured levels of these pollutants in central Cape Town (Muchapondwa 2010). Thus, geomorphology and its political inflections articulate with latitude, condensation, rainfall, building design, and energy use to produce a series of folds that reappear in the nexus of malnutrition, HIV, respiratory disease, and tuberculosis.

The fourth stratum points to the political economic entanglements of contaminated water and agricultural production for globalised food systems. The territory between Khayelitsha, on Cape Town's fringe, and Nkanini, an informal settlement in Stellenbosch, $25 \mathrm{~km}$ away, is filled with agricultural land on which cattle, vegetables, and grapes are cultivated. Farmers worry about their cattle, who graze along the Eerste River and suffer from chronic diarrhoea. A 2010 assessment of microbial loads of the Eerste and Berg rivers and the survival of $\mathrm{E}$. coli on raw vegetables under laboratory conditions showed that Salmonella, Staphylococcus, Listeria, endosporeformers, E. coli and intestinal Enterococci were in abundance in all the sampled sites, which produced acute anxiety for farmers and global exporters whose fresh produce is irrigated by this river water (Govender et al. 2011). An emerging epidemiological literature is now trying to characterise the role of the microbiome in malnutrition, the seasonality of population-wide shifts in microbiome composition (Davenport et al. 2014), and the impact of water and sanitation infrastructural malaise on disease outcomes in South Africa (Ngure et al. 2014; The Lancet 2014; cf. Gandy 2004). In Nonyameko's case, the mentor mother advised her to exclusively breastfeed, citing the risk of diarrhoea if she formula fed. Nonyameko had chosen to formula feed her infant as she was going to leave the child in her mother's care in Lusikisiki while she returned to work in Vredendal. She would struggle to purchase the formula before working again, so would breastfeed until her return to Lusikisiki. For the public health logic that informs the words of the mentor mother, animals, food, children, and diarrhoea become elements in a calculation of costs, risks, and threats (cf. Braun 2007; Hinchliffe and 
Ward 2014; Keck 2015; Lakoff 2013). Thus quantifiable epidemiological evidence on the feedback loops between people, pets, and livestock in dense informal settlements, bring food, livestock, diet, sanitation, infrastructure, and economies into a sentinel logic of vector control and treatment.

The fifth stratum concerns the intense penetration of Khayelitsha by agroindustrial supermarket distribution networks that over-determine what kinds of food are available. Khayelitsha exemplifies the changing dynamics of the South African food system, where the food ecology has transformed in the past two decades as a result of increased local and foreign investment, consolidation of the market among a few corporations, supermarketisation, increased food marketing practices and the expansion of fast food and supermarket chains (Igumbor et al. 2012). Nonyameko, herself employed to pack cucumbers at a large farm for transport to supermarkets, described her diet in Lusikisiki and Khayelitsha as "exactly the same". Large supermarkets had arrived in Lusikisiki not long after their establishment in Khayelitsha in the late 1990s. While rural residents might have previously relied more heavily on small-scale agriculture, supermarkets now constitute a major food source (Reardon et al. 2003). Nonyameko bought maize meal, rice, Lucky Star tinned fish and Koo tinned beans, regardless of whether she was in Lusikisiki, Vredendal or Khayelitsha, as these foods did not require refrigeration and were inexpensive. The supermarkets also facilitated money transfers and the drawing of child grants, and Nonyameko transferred money to her mother in this way. Nonyameko's diet mirrors that of many chronically food insecure residents in Khayelitsha, for whom overall dietary diversity is low. Diets are configured by access to both formal and informal food economies, access to social safety nets, and social networks (Battersby 2011). The overall picture is one of concomitant chronic food insecurity, and malnutrition including undernutrition, obesity and micronutrient lack (cf. Wylie 2001).

In sum, we might say that, like the marble and its network of valleys in Waddington's landscape, the rivers and canals of the Peninsula are obligated to their geological conditions of possibility; that the low-lying wetlands, mist and paraffin stoves and tuberculosis and shack fires, food deserts and obese bodies, migrant domesticities, kin relations and diarrhoea are internal to each other; constituted by those sheets of past as much as by rising and falling sea levels over the last several million years, giving rise to the shape of the rivers and wetlands, and to the forms of racialised spatial regimes of violence that condition the body's posture of relief over the bucket or ditch in the dead of night.

\section{Towards a Political Ecology of the Otherwise}

Strata are neither static nor stacked atop one another, but offer a material analytic for the intra-actions that require attention if an alternative politics of space that counters the negative possibilities of epigenetic and microbial imaginaries in postapartheid Cape Town is to be made sensible. Without this, the performative power of these new scientific discourses still resides in genes, epigenomes, permeable gut membranes, gut-neuronal axes, methylation marks, metabolisms and microbesrendered perceptible as molecularised life (Rose 2007) and thus susceptible to the 
reductionism that Mansfield (2012) cautions against. Considering how the geological (and geomorphological) folds into the microbial, the epigenetic, and the sociological in the particular configurations of the nutrition-sanitation nexus of Cape Town (and beyond) requires a different analytical strategy if the broader political logics that have produced this distribution of hope and harm are to be made sensible, and made otherwise (Povinelli 2011). We argue that a shift in orientation away from the (epigenetic) biopolitics of "life itself" towards a geomorphological sense of the otherwise opens a space for a more productive postgenomic politics. We offer strata as conjunctures-passing entanglements that are temporarily stabilised when distinctions hold briefly-as a rejoin to the increasingly molecularised notion of "environment" courted by new epigenetic and microbiomic science, and the individual body that becomes juxtaposed. Our intention here has been to open the "regimes of perceptibility" afforded by these imaginaries, such that they might hold other political possibilities. The "differentially distributed zones of vulnerability and abandonment" (Povinelli 2011:109) that frame the incidence of adult obesity and childhood diarrhoeal deaths in the city of Cape Town take on a shape beyond the epigenetic and the microbial in this framing, and constitute a topology in which to ground a new political question concerning the opening or closing of possibility for a "new ethics of life and sociability" (2011:109). This allows us to interrogate the emerging knowledge claims around epigenetics and microbiome sciences and track the ways in which their techniques and concepts actualise the eugenic or racialising logics Mansfield (2012) identifies in their archaeology, and ask whether a different epigenetic biopolitics might be on offer. While "responsibilising" discursive possibilities certainly have strong affinities in South African histories of biopolitics (Robins 2006), we seek possibilities for the reshaping of the "contours of perception and imperception" that a conjunctural approach to the spacetimes of epigenetics and microbiome science might afford. Thus, in the friction between the racialising potential of epigenetics and microbiome sciences and the "agential cut" that an intra-actional approach affords us (Barad 2003), we seek to widen the field of debate on how to evaluate not only "what is bad and what is good for the body, for whom, and in what ways" (Guthman and Mansfield 2013:498), but equally for the range of "environments" and persons that act and are acted on. If it is variation or difference that is at stake, and the spatio-temporal, socionatural blurring of categories is to be made more visible, and hence available to political life, then grounded ethnographic descriptions of these processes of "mattering" are required if political epistemologies are to be challenged.

\section{Acknowledgements}

We gratefully acknowledge conversations with Elizabeth Povinelli, and conversations and feedback on earlier drafts from Fiona Ross and the First Thousand Days Research Group at the University of Cape Town; the Indexing the Human Collective at Stellenbosch University; Lou-Marie Kruger and participants in the conference "Disturbing the "Normalised Quiet of Unseen Power': Alternative Ways of Representing Violence" at Stellenbosch University from 31 March to 2 April 2015; Jamie Lorimer, School of Geography and Environment, University of Oxford; and Stanley Ulijaszek and colleagues from the Unit for Biocultural Variation and Obesity at the Institute for Social and Cultural Anthropology, University of Oxford. 


\section{Endnotes}

1 Discourses of "community" in South Africa play a large role in everyday practices of local governance and public health, notwithstanding a long critique from engaged Africanist scholarship (Guyer 1981; Thornton and Ramphele 1989).

2 For a discussion of historical and contemporary politics of apartheid's racial categories, see Erasmus (2008).

3 Territory east of the Great Kei River; later declared as an independent homeland (bantustan) by the apartheid government.

\section{References}

Barad K (2003) Posthumanist performativity: Toward an understanding of how matter comes to matter. Signs 47(4):365-411

Battersby J (2011) "The State of Urban Food Security in Cape Town." Urban Food Security Series No. 11, Queen's University, Kingston, and African Food Security Urban Network (AFSUN)

Black R E, Victora C G, Walker S P, Bhutta Z A, Christian P, de Onis M, Ezzati M, GranthamMcGregor S, Katz J, Martorell R, Uauy R and the Maternal and Child Nutrition Study Group (2013) Maternal and child undernutrition and overweight in low-income and middleincome countries. The Lancet 382(9890):427-451

Braun B (2007) Biopolitics and the molecularization of life. Cultural Geographies 14(1):6-28

Brunn S D and Wilson M W (2013) Cape Town's million plus black township of Khayelitsha: Terrae Incognitae and the geographies and cartographies of silence. Habitat International 39:284-294

Campbell D I, Elia M and Lunn P G (2003) Growth faltering in rural Gambian infants is associated with impaired small intestinal barrier function, leading to endotoxemia and systemic inflammation. Journal of Nutrition 133(5):1332-1338

Canadian Tuberculosis Committee (2007) "Housing Conditions That Serve As Risk Factors For Tuberculosis Infection and Disease." Canada Communicable Disease Report 33(ACS-9)

Cousins T (2007) Spaces of resistance: Informal settlement, communication, and community organisation in a Cape Town township. Urban Studies 44(5/6):979-995

Cousins T (2008) Getting connected: The social dynamics of urban telecommunications access and use in Khayelitsha, Cape Town. New Media and Society 10(9):9-26

Cousins T (2015) HIV and the remaking of hunger and nutrition in South Africa: Biopolitical specification after apartheid. BioSocieties 10(2):143-161

Davenport E R, Mizrahi-Man O, Michelini K, Barreiro L B, Ober C and Gilad Y (2014) Seasonal variation in human gut microbiome composition. PLOS ONE 9(3):e90731

Deleuze G and Guattari F (1987) A Thousand Plateaus: Capitalism and Schizophrenia. Minneapolis: University of Minnesota Press

Doherty T and Sanders D (2011) Implications of the new WHO guidelines on HIV and infant feeding for child survival in South Africa. Bulletin of the World Health Organization 89:62-67

Dupré J (2015) The polygenomic organism. In S Richardson and H Stevens (eds) Postgenomics: Perspectives on Biology and the Genome (pp 56-72). Durham: Duke University Press

Edwards C A and Parrett A (2002) Intestinal flora during the first months of life: New perspectives. British Journal of Nutrition 88(s1):s11-s18

Erasmus Z (2008) Race. In N Shepherd and S Robins (eds) New South African Keywords (pp 169-181). Johannesburg: Jacana

Esposito R (2011) Immunitas: The Protection and Negation of Life. Cambridge: Polity

Fagundes N U, Martins M C, Lima F L, Patricio F R and Toledo M R (1994) Asymptomatic environmental enteropathy among slum-dwelling infants. Journal of the American College of Nutrition 13(1):51-56

Fassin D (2013) Children as victims: The moral economy of childhood in the times of AIDS. In J G Biehl and A Petryna (eds) When People Come First: Critical Studies in Global Health (pp 109-132). Princeton: Princeton University Press 
Gandy M (2004) Rethinking urban metabolism: Water, space, and the modern city. City 8(3):363-379

Godfrey K M, Sheppard A, Gluckman P D, Lillycrop K A, Burdge G C, McLean C, Rodford J, Slater-Jefferies J L, Garratt E, Crozier S R, Starling Emerald B, Gale C R, Inskip H M, Cooper $\mathrm{C}$ and Hanson M A (2011) Epigenetic gene promoter methylation at birth is associated with child's later adiposity. Diabetes 60(5):1528-1534

Govender T, Barnes J M and Pieper C H (2011) Contribution of water pollution from inadequate sanitation and housing quality to diarrheal disease in low-cost housing settlements of Cape Town, South Africa. American Journal of Public Health 101(7): e4-e9

Guthman J and Mansfield B (2013) The implications of environmental epigenetics: A new direction for geographic inquiry on health, space, and nature-society relations. Progress in Human Geography 37(4):486-504

Guyer J (1981) Household and community in African Studies. African Studies Review 24(2):87-137

Hanage W P (2014) Microbiome science needs a healthy dose of scepticism. Nature 512(7514):247-248

Heijmans B T, Tobi E W, Stein A D, Putter H, Blauw G J, Susser E S, Slagboom P E and Lumey L H (2008) Persistent epigenetic differences associated with prenatal exposure to famine in humans. Proceedings of the National Academy of Sciences of the United States of America 105(44):17046-17049

Hinchliffe S and Ward K J (2014) Geographies of folded life: How immunity reframes biosecurity. Geoforum 53:136-144

Hochberg Z, Feil R and Constancia M (2010) Child health, developmental plasticity, and epigenetic programming. Endocrine Reviews 32(2):159-224

Holmes P and Meadows M (eds) (2012) Southern African Geomorphology: Recent Trends and New Directions. Bloemfontein: ASM

Igumbor E U, Sanders D, Puoane T R, Tsolekile L, Schwarz C, Purdy C, Swart R, Durão S and Hawkes C (2012) "Big Food", the consumer food environment, health, and the policy response in South Africa. PLoS Medicine 9(7):e1001253

Ingold T and Palsson G (eds) (2013) Biosocial Becomings: Integrating Social and Biological Anthropology. Cambridge: Cambridge University Press

Jablonka E and Lamb M J (2002) The changing concept of epigenetics. Annals of the New York Academy of Sciences 981:82-96

Jaspan H (2015) "Gut Microbiome, HIV Exposure, and Vaccine Immunogenicity in HIV-Exposed African Infants." Paper presented at the $9^{\text {th }}$ World Congress on Developmental Origins of Health and Disease, Cape Town, November

Kau A L, Ahern P P, Griffin N W, Goodman A L and Gordon I I (2011) Human nutrition, the gut microbiome, and the immune system. Nature 474(7351):327-336

Keck F (2015) Feeding sentinels: Logics of care and biosecurity in farms and labs. BioSocieties 10(2):162-176

Kelly P, Davies S E, Mandanda B, Veitch A, McPhail G, Zulu I, Drobniewski F, Fuchs D, SummerbellaC, Luo N P, Pobee J O M and Farthing M J G (1997) Enteropathy in Zambians with HIV related diarrhoea: Regression modelling of potential determinants of mucosal damage. Gut 41(6):811-816

Lakoff A (2013) A dearth of numbers: The actuary and the sentinel in global public health. Limn 3 http://limn.it/a-dearth-of-numbers-the-actuary-and-the-sentinel-in-global-publichealth (last accessed 22 July 2016)

Lamoreaux J (2016) What if the environment is a person? Lineages of epigenetic science in a toxic China. Cultural Anthropology 31(2):188-214

Landecker H (2011) Food as exposure: Nutritional epigenetics and the new metabolism. BioSocieties 6(2):167-194

Landecker $\mathrm{H}$ and Panofsky P (2013) From social structure to gene regulation and back: A critical introduction to environmental epigenetics for sociology. Annual Review of Sociology 39:333-357

Lawhon M, Ernstson H and Silver S (2014) Provincializing urban political ecology: Towards a situated UPE through African urbanism. Antipode 46(2):497-516 
Legassick M (2006) Forced removals in Greater Cape Town, 1948-1970. Abahlali Online http://abahlali.org/files/ch7Removalscapetown\%20(1).pdf (last accessed 8 June 2016)

Lin A, Arnold B F, Afreen S, Goto R, Huda T M N, Haque R, Raqib R, Unicomb L, Ahmed T, Colford J M and Luby S P (2013) Household environmental conditions are associated with enteropathy and impaired growth in rural Bangladesh. American Journal of Tropical Medicine and Hygiene 89(1):130-137

Lock M (2013) The epigenome and nature/nurture reunification: A challenge for anthropology. Medical Anthropology 32(4):291-308

Lock M (2015) Comprehending the body in the era of the epigenome. Current Anthropology 56(2):151-177

Lohnert B, Oldfield S and Parnell S (1998) Post-Apartheid social polarisations: The creation of sub-urban identities in Cape Town. South African Geographical Journal 80 (2):86-92

Mansfield B (2012) Race and the new epigenetic biopolitics of environmental health. BioSocieties 7(1):352-372

Massey D (2005) For Space. London: Sage

Matthews E H, Taylor P B, Kleingeld M and Geyser M F (2003) Defining a new condensation boundary for low-cost houses in South Africa. Building and Environment 38:1475-1484

Mbuya M N N and Humphrey J H (2016) Preventing environmental enteric dysfunction through improved water, sanitation and hygiene: an opportunity for stunting reduction in developing countries. Material and Child Nutrition 12(Suppl 1):106-120

Meloni M (2010) Biopolitics for philosophers. Economy and Society 39(4):551-566

Meloni M (2015) Epigenetics for the social sciences: Justice, embodiment, and inheritance in the postgenomic age. New Genetics and Society 34(2):125-151

Meloni M (2016) Political Biology: Science and Social Values in Human Heredity from Eugenics to Epigenetics. Basingstoke: Palgrave Macmillan

Meloni M and Testa G (2014) Scrutinizing the epigenetics revolution. BioSocieties 9(4):1-26

Muchapondwa E (2010) A cost-effectiveness analysis of options for reducing pollution in Khayelitsha township, South Africa. Journal for Transdisciplinary Research in Southern Africa 6(2):333-358

Ngure F M, Reid B R, Humphrey J H, Mbuya M N, Pelto G and Stoltzfus R J (2014) Water, sanitation, and hygiene (WASH), environmental enteropathy, nutrition, and early child development: Making the links. Annals of the New York Academy of Sciences 1308:118-128

Niewohner J (2011) Epigenetics: Embedded bodies and the molecularisation of biography and milieu. BioSocieties 6(3):279-298

Pentecost M (2013) "Programmed for vulnerability: Structural Violence and Developmental Programming in the Production of Obesity in South Africa." Unpublished MSc thesis, University of Oxford

Pickersgill M (2016) Epistemic modesty, ostentatiousness, and the uncertainties of epigenetics: On the knowledge machinery of (social) science. In M Meloni, S Williams and P Martin (eds) Biosocial Matters: Rethinking Sociology-Biology Relations in the $21^{\text {st }}$ Century (pp 186-202). Oxford: Blackwell

Pickersgill M, Niewöhner J, Müller R, Martin P and Cunningham-Burley S (2013) Mapping the new molecular landscape: Social dimensions of epigenetics. New Genetics and Society 32(4):429-447

Popkin B M, Adair L S and Ng S W (2011) Global nutrition transition and the pandemic of obesity in developing countries. Nutrition Reviews 70(1):3-21

Povinelli E A (2011) Economies of Abandonment. Durham: Duke University Press

Povinelli E A (2015) Transgender creeks and the three figures of power in late liberalism. Differences 26(1):168-187

Prendergast A J, Rukobo A, Chasekwa B, Mutasa K, Ntozini R, Mbuya M N, Jones A, Moulton L $\mathrm{H}$, Stoltzfus R J and Humphrey J H (2014) Stunting is characterized by chronic inflammation in Zimbabwean infants. PLoS One 9(2):e86928

Prescott S L (2013) Early-life environmental determinants of allergic diseases and the wider pandemic of inflammatory noncommunicable diseases. Journal of Allergy and Clinical Immunology 131(1):23-30

Reardon T, Timmer C P, Barrett C B and Berdegué J (2003) The rise of supermarkets in Africa, Asia, and Latin America. American Journal of Agricultural Economics 85(5):1140-1146 
Richardson S (2015) Maternal bodies in the postgenomic order: Gender and the explanatory landscape of epigenetics. In S Richardson and H Stevens (eds) Postgenomics: Perspectives on Biology and the Genome (pp 210-231). Durham: Duke University Press

Richardson S and Stevens H (2015) Approaching postgenomics. In S Richardson and H Stevens (eds) Postgenomics: Perspectives on Biology and the Genome (pp 232-242). Durham: Duke University Press

Robins S (2006) From "rights" to "rituals": AIDS activism in South Africa. American Anthropologist 108(2):312-323

Rose N (2007) The Politics of Life Itself. Princeton, NJ: Princeton University Press

Saloojee H, Grey G and Mclntyre J A (2011) HIV and infant feeding: One step forward, two steps back. Southern African Journal of HIV Medicine 12(4):6-10

Shostak S and Moinester M (2015) The missing piece of the puzzle? Measuring the environment in the postgenomic moment. In S Richardson and H Stevens (eds) Postgenomics: Perspectives on Biology and the Genome (pp 192-209). Durham: Duke University Press

Silver K L and Singer P A (2014) SDGs: Start with maternal, newborn, and child health cluster. The Lancet 384(9948):1093-1094

Slack J M W (2002) Conrad Hal Waddington: The last Renaissance biologist? Nature Reviews: Genetics 3(11):889-995

Spears D, Ghosh A and Cumming O (2013) Open defecation and childhood stunting in India: An ecological analysis of new data from 112 districts. PLOS ONE 8(9):e73784

Swanson M W (1977) The sanitation syndrome: Bubonic plague and urban native policy in the Cape Colony, 1900-1909. Journal of African History 18(3):387-410

Thamm M (2014) Active citizenship: How Khayelitsha residents are leading the charge. Daily Maverick 1 October http://www.dailymaverick.co.za/article/2014-10-01-active-citizenshiphow-khayelitsha-residents-are-leading-the-charge (last accessed 3 December 2015)

The Lancet (2014) Water and sanitation: Addressing inequalities. 383(9926):1359

Thompson A L (2012) Developmental origins of obesity: Early feeding environments, infant growth, and the intestinal microbiome. American Journal of Human Biology 24(3):350-360

Thornton R J and Ramphele M (1989) Community: Concept and practice in South Africa. Critique of Anthropology 9(1):75-87

Tobi E W, Lumey L H, Talens R P, Kremer D, Putter H, Stein A D, Slagboom P E and Heijmans B $T$ (2009) DNA methylation differences after exposure to prenatal famine are common and timing- and sex-specific. Human Molecular Genetics 18(21):4046-4053

Tsing A L (2005) Friction: An Ethnography of Global Connection. Princeton: Princeton University Press

Waddington C H (1942) The epigenotype. Endeavour 1:18-20

Waggoner M R and Uller T (2015) Epigenetic determinism in science and society. New Genetics and Society 34(2):177-195

Warin M, Moore V, Davies M and Ulijaszek S (2016) Epigenetics and obesity: The reproduction of habitus through intracellular and social environments. Body and Society 22(4):53-78

Warin M, Zivkovic T, Moore V and Davies M (2012) Mothers as smoking guns: Fetal overnutrition and the reproduction of obesity. Feminism and Psychology 22(3):360-375

Westwood A and Claasen J (2010) Childhood in-hospital mortality from acute gastro-enteritis in Cape Town. South African Medical Journal 100(4):196

Wilson E A (2004) Psychosomatic: Feminism and the Neurological Body. Durham: Duke University Press

Wylie D (2001) Starving On a Full Stomach: Hunger and the Triumph of Cultural Racism in South Africa. Charlottesville: University of Virginia Press

Yates-Doerr E (2011) Bodily betrayal: Love and anger in the time of epigenetics. In F E MasciaLees (ed) A Companion to the Anthropology of the Body and Embodiment (pp 292-306). Chichester: Wiley-Blackwell

Zunza M, Theron G B and Harvey C (2011) Compliance with infant formula feeding by HIVpositive women one week after delivery in Khayelitsha, South Africa. South African Journal of Epidemiology and Infection 26(4):274-279 